\title{
ANALYSIS OF COMMUNITY PERCEPTION ON THE IMPACT OF SAND MINING IN MUJUR RIVER AND REGOYO RIVER
}

\author{
Ike Kumala Sari ${ }^{1 *}$, Sudarti Sudarti ${ }^{2}$ \\ ${ }^{1}$ Student of Physics Education, Universitas Jember, Jember \\ ${ }^{2}$ Lecturer of Physics Education, Universitas Jember, Jember \\ Correspondence Email: ikekumalasari47@gmail.com
}

Submission: November 22, 2021

Publication: December 5, 2021

\begin{abstract}
Sand mining is an activity of exploiting natural resources below the surface of the ground that can be carried out underground river flows to extract minerals, namely sand. Sand mining is generally carried out to increase development. This activity has a positive impact on the community. However, if you ignore the environmental impact analysis, it will harm the community, which can cause environmental damage. Therefore, this study aims to analyze public perceptions of the impact of sand mining on the Mujur River and the Regoyo River. The research method used is a survey and data obtained by conducting observations, documentation, and questionnaires. Respondents in this study amounted to 30 people who are the surrounding community. For one month, this research was conducted around the Mujur River and the Regoyo River, Pasirian District, Lumajang Regency, East Java. The data of this study were analyzed using descriptive analysis. This study indicates the high public perception of the impact of sand mining on the Mujur River and Regoyo River, seen from the percentage of the questionnaire calculation, which is divided based on the positive and negative impacts of sand mining on the Mujur River and Regoyo River.
\end{abstract}

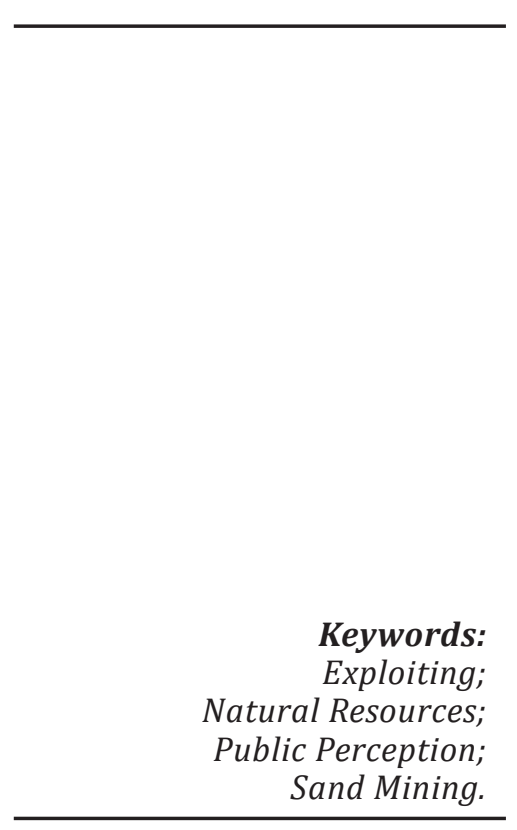

This work is licensed under a CC BY-4.0 License

\section{INTRODUCTION}

Indonesia is one of the countries with abundant natural resources, so these natural resources must be appropriately utilized. Natural resources that are misused can cause environmental damage. Sand mining in rivers that damage environmental damage analysis is one form of environmental destruction. Based on Article 1 point 16 of Law No. 32 of 2009 on Environmental Protection and Management, explains that:

"To Damage Environment shall be an act of people who pose direct or indirect changes of physical, chemical and/or biological conditions of environment that exceed the standardized criteria of environmental damage."

The existence of sand mining in an area is due to several factors, including the company's desire to provide the materials needed for building projects and the increasing demand 
for materials for housing construction, road infrastructure, and buildings. In addition, strategic areas are also a factor that is the reason for sand mining (Aswan, et al., 2020).

Sand mining is a natural resource exploitation activity that can support development. Mining can generate a large amount of income for a country. Along with the development of facilities and infrastructure in Indonesia, the need for construction excavation materials such as sand is increasing (Firdaus, 2019).

Sand mining provides a significant contribution to Original Local Government Revenue in each region and can improve the economy of sand mining actors. Sand mining activities can be regarded as activities that can damage the environment. It can happen when the mining is not managed correctly. Sand mining can cause environmental impacts, both positive and negative impacts.

The positive impact of sand mining is to absorb labor, reduce unemployment, create jobs, reduce poverty, and increase the local communities' income (Nurcahyo \& Muzayanah, 2020). The existence of sand mining facilitates the fulfillment of local sand material needs at lower prices and short order times (Halukati \& Isa, 2020). Then we can see that the impact of sand mining in the river can trigger various possibilities that occur, both in people's lives and in the environment (Indarta, 2020). According to Fitri Qolbina, et al. (2017), sand mining owners are generally families above the poverty line.

The negative impact of sand mining can be seen from an environmental point of view. Sand mining carried out in coastal areas causes the loss of fishing areas due to sea sand dredging and results in marine police patrols, which makes fishers feel pressured and no longer have the freedom to catch fish as they used to (Anggariani, et al., 2020). Sand mining in rivers can cause environmental damage, such as damage to embankments, which can cause landslides on embankments and cause bumpy roads caused by trucks loaded with sand. Damage to the road infrastructure can cause accidents along damaged roads (Indarta, 2020). Sand mining in the river also causes the river body to widen. It is caused by erosion. The depth of the river is getting shallower as a result of deposition. In addition, the quality of river water will decrease, which can cause river water pollution (Tamrin, et al., 2018).

The sand miners in mining activities must consider the correct method used to carry out the sand mining. So that later, it will reduce the negative impact caused by sand mining activities. One of them is to reduce soil erosion (Asabonga, et al., 2016).

Lumajang is one of the regencies in East Java, which has abundant natural resources. The total area of Lumajang Regency is $1,790.90 \mathrm{~km}^{2}$, with a population of $1,6,064,343$ people. This region consists of 21 sub-districts with seven sub-districts and 168 villages. When viewed from its geographical location, Lumajang is at coordinates $112^{\circ} 53^{\prime}-113^{\circ} 23^{\prime}$ East Longitude and $7^{\circ} 54^{\prime}-8^{\circ} 23^{\prime}$ South Latitude (Safa'at \& Qurbani, 2017). 
Lumajang Regency is located quite close to several mountains, including Bromo, Semeru, and Tengger, where 60,000 hectares of land are volcanic mines with excellent quality. With abundant resources and various kinds of utilization, it can be used as a source of new business that absorbs much labor to increase the local community's income. Sand mining locations in Lumajang Regency are located along the Rejali River, Regoyo River, Mujur River, and Glidig River, which are in Candipuro, Pasirian, Pronojiwo, and Tempursari Districts with an area of approximately 82.50 hectares (Safa'at \& Qurbani, 2017).

According to Safa'at \& Qurbani (2017), the negative impact of sand mining in Lumajang Regency is excessive exploitation using excavators, resulting in environmental damage. Initially, areas along the south coast which were agricultural areas, have turned into mining areas which have resulted in reduced agricultural land, and Lumajang Regency has become an area Lumajang Regency has become an area prone to floods and tsunamis in spatial planning.

According to Wicaksono \& Nasution (2020), another negative impact of sand mining in Lumajang Regency is the existence of a sand mining conflict in Selok Awar-Awar Village, Pasirian District, Lumajang Regency caused by the plan to exploit iron sand by PT. IMMS in Lumajang and establishing a sand mine in the Selok Awar-Awar Village in 2010. The existence of sand mining made communities uncomfortable and restless. It is because the activity of sand hauling trucks controlled all the roads used by communities.

Based on description above, this study aims to analyze public perceptions about the impact of sand mining on the Mujur River and the Regoyo River. The location is a significant mining location in the Pasirian District, Lumajang Regency, East Java.

\section{METHOD}

This research was conducted using a qualitative research type. According to Erikson in Anggito \& Setiawan (2018), qualitative research is research that seeks to describe narratively the activities carried out and the impact of the actions taken on life.

This research was conducted in the Mujur River and Regoyo River areas, precisely in Pasirian District, Lumajang Regency, East Java Province. This location was chosen because sand mining activities are in the river and mining activities in the Mujur River and Regoyo River areas cause road damage, air pollution, warmer environmental temperatures, and other losses. Respondents in this study were the surrounding communities, amounting to 30 people. The study was carried out for one month and carried out in October 2021. The types of data and data sources used in this study are as follows: 
1. Primary Data

Primary data is data obtained directly in the field as well as responses from the community.

2. Secondary Data

Secondary data is data obtained from several sources, such as literature reviews related to the research conducted. The data needed in this study were obtained using the following data collection techniques:

a. Observation

Observation is a technique of collecting data directly from the field. The observed data is a picture of attitudes, behavior, actions, or interactions between humans (Raco, 2010). In general, observation can be interpreted as a way to accommodate various information done by systematically observing and recording the phenomena used as objects of observation (Djaali, et al., 2000). Researchers made direct observations about the impact of sand mining activities on the Mujur River and Regoyo River on the surrounding community. The objects observed are sand mining activities and the impact on the community around the river.

b. Questionnaire

The questionnaire is a data collection technique that can be arranged in various ways. The questionnaire contains a list of structured questions with available answer choices, and then the respondent chooses the answer according to his perception (Nugroho, 2018).

c. Documents

In this study, the documents used were in the form of photos and notes from field observations. Documentation is used to obtain sand mining activities carried out in the Mujur River and Regoyo River. Documentation is done using improvised tools, namely mobile phones.

In this study, data analysis was carried out quantitatively with the help of tables explaining the results of the questionnaires for the community around Mujur River and Regoyo River, Pasirian District, Lumajang Regency. Next, the table will be explained using a description. The calculation of the questionnaire score is as follows:

$$
\begin{aligned}
& \mathrm{SA}=\mathrm{F} \times 4 ; \\
& \mathrm{A}=\mathrm{F} \times 3 ; \\
& \mathrm{DS}=\mathrm{F} \times 2 ; \text { and } \\
& \mathrm{SD}=\mathrm{F} \times 1 .
\end{aligned}
$$

Where $\mathrm{F}$ is the frequency. The maximum score if the respondent chooses to agree is 120. Then the percentage calculation is calculated using the following formula:

(total score) / (maximum score) x 100\% 


\section{RESULTS AND DISCUSSION}

\section{A. Field Observation Results}

There are quite some mining locations in Pasirian District, some of which are in the Mujur River and the Regoyo River. The results of mining observations in the Mujur River can be shown in the image below.

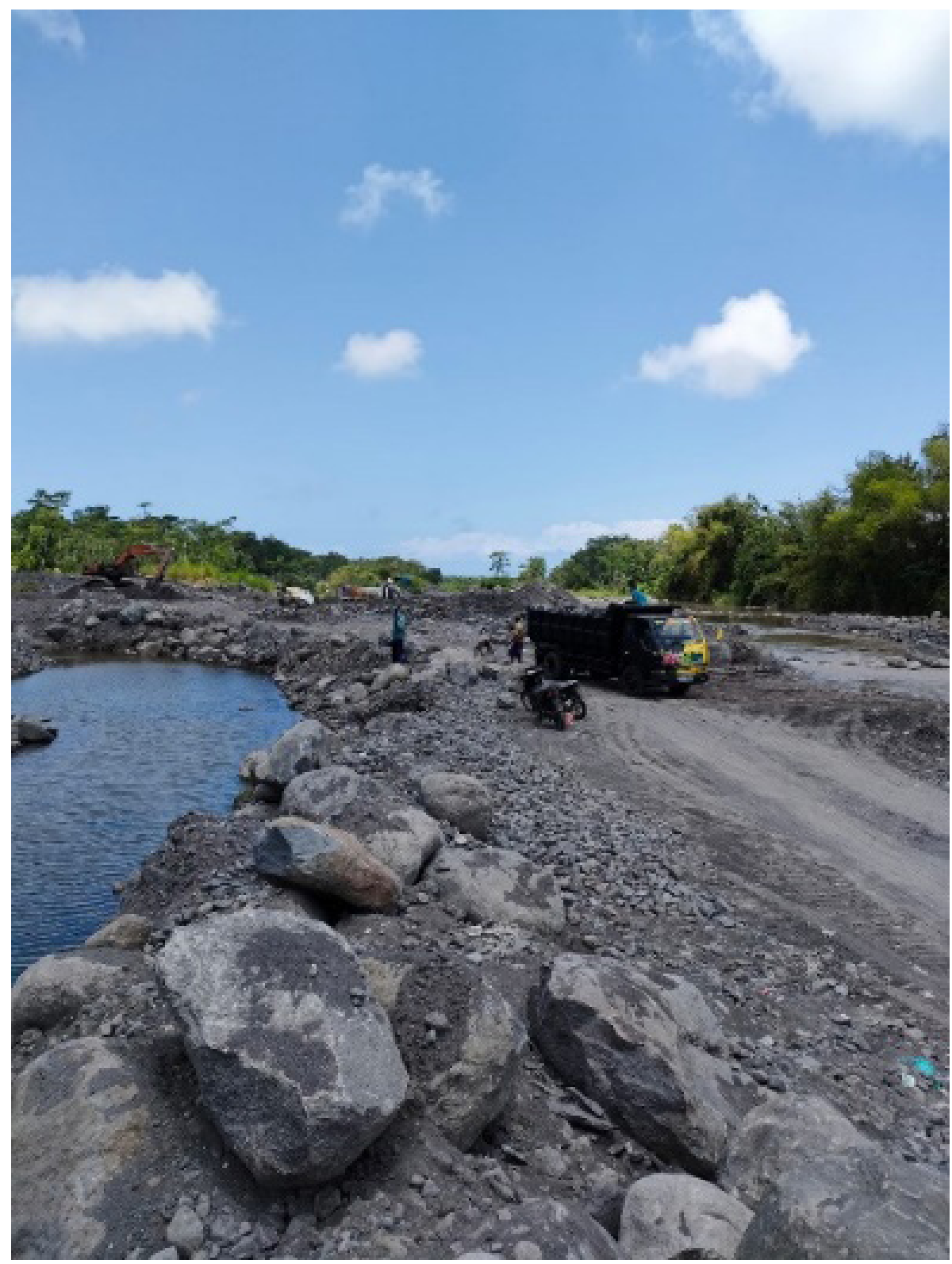

Figure 1. Mining in the Mujur River

The state of the sand mining location can be said to be of concern. It is due to a large amount of dust before entering the mining area. The journey to the mining site passes through a damaged road. The mining location is further from the settlement than the mining location on the Regoyo River. Mining at this location still uses direct human power because it does not use heavy excavators so much. At this location, not only natural resources of sand are taken, but also natural resources of rock. Mining entrepreneurs and workers do not consider environmental damage 
analysis. Ex-mining carried out by workers leaves many excavation pits. It results in an uneven ground surface and can cause environmental damage. The mining of sand around this Mujur River causes road damage due to many trucks loaded with sand crossing the road. It resulted in the disruption of the activities of the surrounding community because the road is one of the access roads used by the surrounding community. The sand mining activity also results in air pollution, noise pollution, and an increasingly hot environmental temperature. The results of mining observations in the Regoyo River can be shown in the image below.

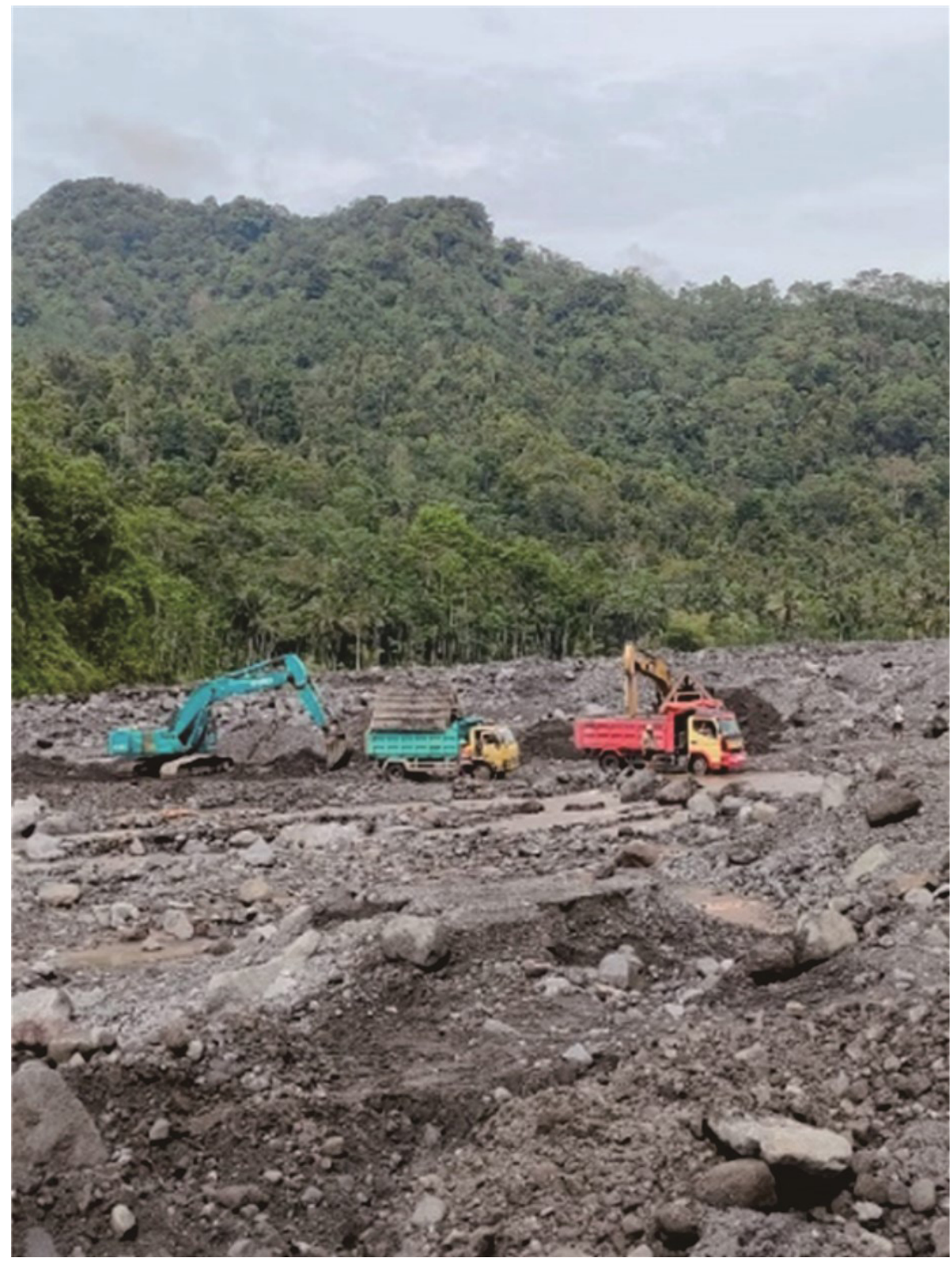

Figure 2. Mining in the Regoyo River

The condition of the mining site on the Regoyo River is also quite alarming. Even more concerning than mining on the Mujur River. It happened because before entering the mining area, there was already much dust and the journey to the mining site passed through a heavily damaged access road. This damaged road during the rainy season will be very problematic. The road is one of the access 
roads the surrounding community uses to carry out their activities, so the access roads with potholes and bumps will hinder community activities.

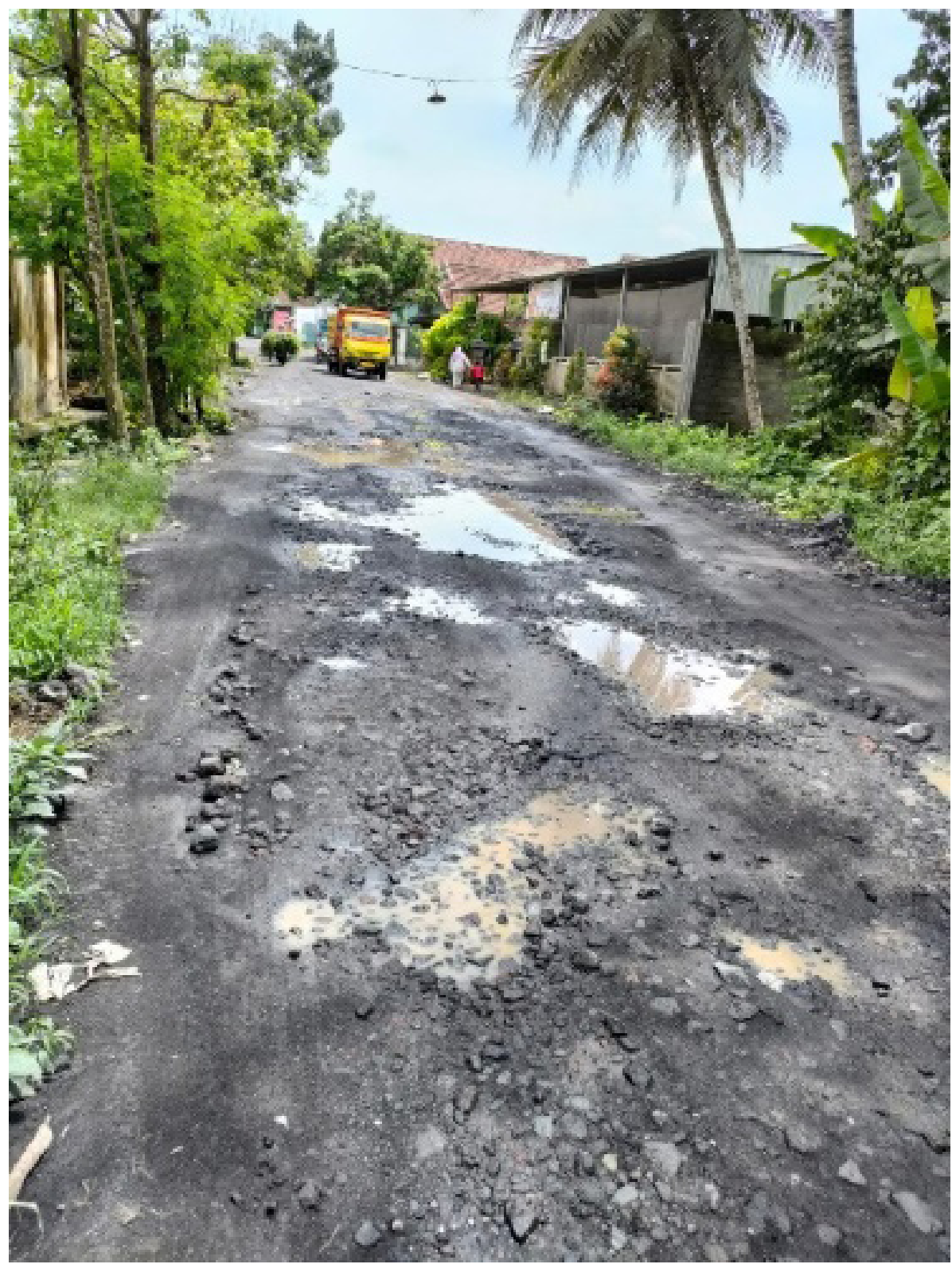

Figure 3. Road Damage

Many mining entrepreneurs and workers do not pay attention to the impact of their mining activities. Mining at this location uses a lot of heavy excavators. Exmining sites carried out by deep excavation exploration methods leave a lot of scars. The former mining site has an uneven ground surface, which affects the surrounding environmental conditions.

The land used for sand mining activities on the Regoyo River is close to residential areas. It disturbed the communitiess for several reasons, including the dust generated from the daily mobility of the sand trucks making the communities' houses dirty, the noise produced by the sand trucks disrupting the activities of the communitiess, damaged road access that could hinder the mobility of the communitiess, the 
surrounding air became hotter, and so forth. The access road through which the sand-carrying trucks pass is close to several schools. The schools are Kindergarten (TK) and Elementary School (SD). As we know that the school level is the age of the children, so it is hazardous if many sand trucks pass through the access road.

Based on previous research, the location of sand mining in Lumajang Regency is a sand mining that produces sand with the number one iron content for building construction. The Department of Energy and Mineral Resources of East Java Province states that the iron content is between $48.5 \%$ to $50.2 \%$ and the East Java construction project sets Lumajang sand as a building specification (Safa'at and Qurbani, 2017). So it is not surprising that the demand for sand building materials is increasing, resulting in more land being used for sand mining activities.

Sand from the mining of sand from the Mujur River and the Regoyo River is usually stockpiled somewhere. The place used by the entrepreneur initially used unused land for agricultural activities. Nevertheless, for now, the land used to stockpile the results of sand mining is agricultural land. It is because the cost of renting agricultural land used to stockpile the price of sand is quite tempting for the community. So many communities rent out their land, even sell their land for sand dumping. It makes agricultural land in the area around the Mujur River and the Regoyo River narrower.

According to Wicaksono \& Nasution (2020), another negative impact of sand mining in the Lumajang Regency is a sand mining conflict in Selok Awar-Awar Village, Pasirian District, Lumajang Regency caused by the iron sand exploitation plan by PT. IMMS in Lumajang and established a sand mine in Selok Awar-Awar Village in 2010. The existence of sand mining made communities uncomfortable and restless. It is because all the roads used by commuinities for their activities are controlled by sand mining trucks. For now, the conflict has begun to subside, but the community are still not comfortable with the sand trucks passing through their access road, so communitiess often protest against the sand truck drivers. They protested by closing the road by giving drums filled with stones beside the road until it was narrow so that sand trucks could not pass through it.

\section{B. Questionnaire Results of Neighborhood Community}

Public perceptions of the impact of sand mining were obtained by distributing questionnaires to the surrounding community. In this study, the distributed questionnaire had four answer options that the respondents had to choose from. The answer choices include SA (Strongly Agree), A (Agree), DS (Disagree), and SD (Strongly Disagree). The choice of SA has a score of four, A has a score of three, DS has a score of 2 , and SD has a score of 1 . The questionnaire distributed is divided into 2 , namely regarding the positive impact and negative impact. The classification of percentage assessment criteria based on the calculation results is as follows 
Sari, I. K. \& Sudarti, S. Analysis of Community Perception on the Impact ...

Table 1. Presentation Assessment Criteria Classification

\begin{tabular}{c|c|c}
\hline \hline No & Percentage & Assesment Criteria \\
\hline \hline 1 & $25 \%-43,75 \%$ & Very Low \\
\hline 2 & $43,75 \%-62,5 \%$ & Low \\
\hline 3 & $62,5 \%-81,25 \%$ & High \\
\hline 4 & $81,25 \%-100 \%$ & Very High \\
\hline \hline
\end{tabular}

Table 2. Results of the Questionnaire on the Positive Impact on Sand Mining

\begin{tabular}{|c|c|c|c|c|c|c|c|}
\hline \multicolumn{2}{|l|}{ Question } & SA & A & D & SD & Total & Score \\
\hline \multirow{2}{*}{$\begin{array}{l}\text { Sand mining adds to the income of } \\
\text { the community around the Mujur } \\
\text { River and the Regoyo River }\end{array}$} & Frequency & 7 & 19 & 3 & 1 & 120 & \multirow{2}{*}{$76,6 \%$} \\
\hline & Score & 28 & 57 & 6 & 1 & 92 & \\
\hline \multirow[t]{2}{*}{ Sand mining reduces unemployment } & Frequency & 11 & 17 & 2 & - & 120 & \multirow{2}{*}{$82,5 \%$} \\
\hline & Score & 44 & 51 & 4 & 0 & 99 & \\
\hline \multirow[t]{2}{*}{ Sand mining opens up new jobs } & Frequency & 9 & 19 & 1 & 1 & 120 & \multirow{2}{*}{$80 \%$} \\
\hline & Score & 36 & 57 & 2 & 1 & 96 & \\
\hline \multirow[t]{2}{*}{ Sand mining absorbs labor } & Frequency & 6 & 18 & 2 & - & 120 & \multirow{2}{*}{$78,3 \%$} \\
\hline & Score & 36 & 54 & 4 & - & 94 & \\
\hline \multirow{2}{*}{$\begin{array}{l}\text { Sand mining makes building } \\
\text { materials, namely sand, easy to } \\
\text { obtain at low prices }\end{array}$} & Frequency & 9 & 16 & 5 & - & 120 & \multirow{2}{*}{$78,3 \%$} \\
\hline & Score & 36 & 48 & 10 & - & 94 & \\
\hline \multirow{2}{*}{$\begin{array}{l}\text { Sand mining makes building } \\
\text { materials, namely sand, easy to } \\
\text { obtain in a short time }\end{array}$} & Frequency & 7 & 19 & 4 & - & 120 & \multirow{2}{*}{$77,5 \%$} \\
\hline & Score & 28 & 57 & 8 & - & 93 & \\
\hline
\end{tabular}

Table 3. The Results of the Questionnaire on the Negative Impact of Sand Mining

\begin{tabular}{|c|c|c|c|c|c|c|c|}
\hline \multicolumn{2}{|l|}{ Question } & SA & A & D & SD & Total & Score \\
\hline \multirow[t]{2}{*}{ Sand mining causes air pollution } & Frequency & 7 & 18 & 5 & - & 120 & \multirow{2}{*}{$76,6 \%$} \\
\hline & Score & 28 & 54 & 10 & - & 92 & \\
\hline \multirow[t]{2}{*}{ Sand mining causes erosion } & Frequency & 5 & 20 & 4 & 1 & 120 & \multirow{2}{*}{$74,1 \%$} \\
\hline & Score & 20 & 60 & 8 & 1 & 89 & \\
\hline \multirow{2}{*}{$\begin{array}{l}\text { Sand mining causes river water to be } \\
\text { polluted }\end{array}$} & Frequency & 1 & 21 & 7 & 1 & 120 & \multirow{2}{*}{$67,5 \%$} \\
\hline & Score & 4 & 63 & 14 & 1 & 81 & \\
\hline \multirow{2}{*}{$\begin{array}{l}\text { Sand mining causes damage to road } \\
\text { access }\end{array}$} & Frequency & 11 & 17 & 1 & 1 & 120 & \multirow{2}{*}{$81,6 \%$} \\
\hline & Score & 44 & 51 & 2 & 1 & 98 & \\
\hline \multirow{2}{*}{$\begin{array}{l}\text { Sand mining causes accidents due to } \\
\text { damaged roads to increase }\end{array}$} & Frequency & 11 & 18 & 1 & - & 120 & \multirow{2}{*}{$83,3 \%$} \\
\hline & Score & 44 & 54 & 2 & - & 100 & \\
\hline
\end{tabular}




\begin{tabular}{|c|c|c|c|c|c|c|c|}
\hline \multicolumn{2}{|l|}{ Question } & SA & $\mathbf{A}$ & D & SD & Total & Score \\
\hline \multirow{2}{*}{$\begin{array}{l}\text { Sand mining causes rivers to become } \\
\text { more muddy and shallow }\end{array}$} & Frequency & 6 & 20 & 4 & - & 120 & \multirow{2}{*}{$86,6 \%$} \\
\hline & Score & 36 & 60 & 8 & - & 104 & \\
\hline \multirow{2}{*}{$\begin{array}{l}\text { Sand mining causes the } \\
\text { environmental temperature to get } \\
\text { hotter }\end{array}$} & Frequency & 4 & 18 & 8 & - & 120 & \multirow{2}{*}{$71,6 \%$} \\
\hline & Score & 16 & 54 & 16 & - & 86 & \\
\hline
\end{tabular}

Based on the questionnaire results distributed to 30 respondents, it was found that the community's perception of sand mining in the Mujur River and Regoyo River was based on a positive impact; namely $76.6 \%$ of the community agreed that sand mining increased the income of the surrounding community. A total of $82.5 \%$ of people agree that sand mining reduces unemployment, $80 \%$ of people agree that sand mining creates new jobs, $78.3 \%$ of people agree that sand mining absorbs labor, $78.3 \%$ of people agree that sand mining makes materials Building materials, namely sand, are obtained at low prices, and $77.5 \%$ of the people agree that sand mining makes building materials, namely sand, easily obtained in a short time. The results of the questionnaire showed a percentage of $76.6 \%$ to $82.5 \%$. It means that according to the classification of the assessment results, the percentage of the questionnaire results is included in the criteria of high to very high.

The results of the questionnaire are based on negative impacts, namely $76.6 \%$ of the community agree that sand mining causes air pollution, $74.1 \%$ of the community agree that sand mining causes erosion, $67.5 \%$ of the community agrees that sand mining causes polluted river water, $81.6 \%$ of the community agree that sand mining causes damage to road access, $83.3 \%$ of people agree that sand mining causes the accident rate due to damaged roads to increase, and $86.6 \%$ of people agree that sand mining causes rivers to become more murky and shallow. The results of the questionnaire showed a percentage of $67.5 \%$ to $83.3 \%$. According to the assessment classification, the percentage of questionnaire results is included in the high to very high criteria.

\section{CONCLUSIONS AND SUGGESTIONS}

Based on the results of the analysis of public perceptions about the impact of sand mining on the Mujur River and the Regoyo River, it can be concluded that the community has a high perception seen from the calculation of the questionnaire. The percentage calculation is included in the high to very high criteria according to the assessment classification. It means that the people around the Mujur River and Regoyo River think that sand mining in the Mujur River and Regoyo River, Pasirian District, Lumajang Regency has positive and negative impacts on the community. The positive impact is that it can increase people's income, reduce unemployment, create new jobs, absorb labor, make building materials, namely sand, easily obtained at low prices, and make building materials, namely sand, easily obtained in a short time. While the negative 
impact is causing air pollution, it is causing erosion, causing polluted rivers, causing damage to road access, causing the rate of road accidents due to damaged roads to increase, and causing the river to be increasingly cloudy and shallow. Based on this conclusion, the negative impact of sand mining should receive special attention from various parties: the government, the surrounding community, and sand mining entrepreneurs. Sand mining entrepreneurs must carry out environmental damage analysis to minimize or eliminate the negative impacts of sand mining activities so that there is no conflict between communities and sand mining entrepreneurs.

\section{REFERENCES}

Anggariani, D., et al. (2020). Tambang Pasir dan Dampak Sosial Ekonomi Masyarakat di Pesisir Pantai. SIGn Journal of Social Science, CV. Social Politic Genius (SIGn), 1(1), 15-29. doi: https://doi.org/10.37276/sjss.v1i1.96

Anggito, A. \& Setiawan, J. (2018). Metodologi Penelitian Kualitatif. Sukabumi: CV. Jejak.

Asabonga, M., et al. (2016). The Physical and Environmental Impact of Sand Mining. Transactions of the Royal Society of South Africa, Taylor \& Francis, 72(1), 1-5. doi: https://doi.org/10.1080/0035919X.2016.1209701

Aswan, A., et al. (2020). Usaha Tambang Pasir Batu di Desa Lonjoboko Kabupaten Gowa, 2006-2018. Attoriolong, Universitas Negeri Makassar, 18(1), 101-112.

Djaali, D., et al. (2000). Pengukuran dalam Bidang Pendidikan. Jakarta: Program Pascasarjana Universitas Negeri Jakarta.

Firdaus, F. (2019). Dampak Lingkungan dan Sosial Penggalian Pasir Sepanjang Aliran Sungai di Kota Bima (Studi di Kelurahan Rabadompu Timur Kota Bima). Jurnal Komunikasi dan Kebudayaan, Sekolah Tinggi Ilmu Sosial dan Ilmu Politik Mbojo Bima, 6(1), 9-26.

Halukati, M. \& Isa, A. H. (2020). Dampak Penambangan Pasir terhadap Kelestarisan Lingkungan di Kelurahan Tumbihe. Jambura Journal of Community Empowerment, Universitas Negeri Gorontalo, 1(2), 44-52. doi: https://doi.org/10.37411/jjce.v1i2.464

Indarta, D. W. (2020). Dampak Kegiatan Penambangan Pasir Secara Mekanik terhadap Ligkungan di Kabupaten Bojonegoro. Jurnal Hukum Justitiable, Universitas Bojonegoro, 2(2), 42-53.

Law of the Republic of Indonesia Number 32 of 2009 on Environmental Protection and Management (State Gazette of the Republic of Indonesia of 2009 Number 140, Supplement to State Gazette of the Republic of Indonesia Number 5059).

Nugroho, E. (2018). Prinsip-Prinsip Menyusun Kuesioner. Malang: Brawijaya Press.

Nurcahyo, A. D. \& Muzayanah, M. (2020). Analisis Dampak Penambangan Pasir Berbasis Pembangunan Berkelanjutan di Kecamatan Ngebel Kabupaten Ponorogo. Jurnal Geografi: Geografi dan Pengajarannya, Universitas Negeri Surabaya, 18(2), 139144. doi: https://doi.org/10.26740/jggp.v18n2.p139-144 
Qolbina, F., et al. (2017). Dampak Kegiatan Pertambangan Pasir terhadap Pendapatan Keluarga Pemilik Tambang di Desa Petapahan Kecamatan Tapung Kabupaten Kampar. Jurnal Online Mahasiswa Fakultas Ekonomi Universitas Riau, Universitas Riau, 4(1), 1266-1280.

Raco, J. R. (2010). Metode Penelitian Kualitatif: Jenis, Karakteristik dan Keunggulannya. Jakarta: Grasindo.

Safa'at, R. \& Qurbani, I. D. (2017). Alternatif Penyelesaian Sengketa Pertambangan (Studi di Kabupaten Lumajang Provinsi Jawa Timur).Jurnal Konstitusi, Mahkamah Konstitusi RI, 14(1), 151-167. doi: https://doi.org/10.31078/jk1417

Tamrin, T., et al. (2018). Analisis Kegiatan Penambangan Pasir Batu terhadap Erosi, Kualitas Air dan Sosial Ekonomi Masyarakat di Sekitar Sungai Indragiri. Photon: Jurnal Sain dan Kesehatan, Universitas Muhammadiyah Riau, 8(2), 67-74. doi: https://doi.org/10.37859/jp.v8i2.718

Wicaksono, A. N. \& Nasution, N. (2020). Konflik Tambang Pasir Besi di Desa Selok Awar-Awar Kecamatan Pasirian Kabupaten Lumajang Tahun 2015. Avatara: E-Journal Pendidikan Sejarah, Universitas Negeri Surabaya, 9(2), 1-9.

I Sari, I. K. \& Sudarti, S. (2020). Analysis of Community Perception on the Impact of I Sand Mining in Mujur River and Regoyo River. SIGn Journal of Social Science, CV. Social I Politic Genius (SIGn), 2(2), 1-12. doi: https://doi.org/10.37276/sjss.v2i2.120 